\title{
AQUATIC MACROPHYTES AS FEEDING SITE FOR SMALL FISHES IN THE ROSANA RESERVOIR, PARANAPANEMA RIVER, SOUTHEASTERN BRAZIL
}

\author{
CASATTI, L., ${ }^{1}$ MENDES, H. F. ${ }^{2}$ and FERREIRA, K. M. ${ }^{1}$ \\ ${ }^{1}$ Laboratório de Ictiologia de Ribeirão Preto, FFCLRP-USP, Av. Bandeirantes, 3900, CEP 14040-901, \\ Ribeirão Preto, SP, Brazil \\ ${ }^{2}$ Laboratório de Entomologia Aquática, FFCLRP-USP, Av. Bandeirantes, 3900, CEP 14040-901, \\ Ribeirão Preto, SP, Brazil \\ Correspondence to: Lilian Casatti, Laboratório de Ictiologia, Departamento de Zoologia e Botânica, IBILCE/ \\ UNESP, Rua Cristóvão Colombo, 2265, Jardim Nazareth, CEP 15054-000, São José do Rio Preto, SP, \\ Brazil, e-mail: 1casatti@bot.ibilce.unesp.br \\ Received February 13, 2002 - Accepted May 29, 2002 - Distributed May 31, 2003
}

(With 3 figures)

\begin{abstract}
In the present investigation we studied the feeding habits of the fishes associated with aquatic macrophytes in the Rosana Reservoir, southeastern Brazil. Twenty fish species were collected during four field trips, regularly distributed across the dry and wet seasons. Focal snorkeling observations of the fishes were made over a total of six hours. Nine species were present in abundances of more than $1 \%$ and, therefore, had their feeding habits analyzed. Hemigrammus marginatus, Roeboides paranensis, Hyphessobrycon eques, Astyanax altiparanae, Serrasalmus spilopleura, and Bryconamericus stramineus were predominantly invertivores, with predominance of aquatic insects (Diptera, Ephemeroptera, and Trichoptera immatures) among their food items. The predominantly algivores were Apareiodon affinis, Serrapinnus notomelas, and Satanoperca pappaterra, with high frequency of filamentous blue-green algae, diatoms, clorophyts, and periderm. The different microhabitat exploitation plus diet composition suggests partitioning of resources and absence of food competition among the most representative fish species in the studied community, indicating the importance of the naturalistic approach to fish ecology studies.
\end{abstract}

Key words: aquatic macrophytes, fishes, feeding, Rosana Reservoir, Paranapanema River.

\section{RESUMO}

\section{Macrófitas aquáticas como sítio de alimentação para pequenos peixes no reservatório de Rosana, rio Paranapanema, Sudeste do Brasil}

Neste trabalho foram estudados os hábitos alimentares dos peixes associados a bancos de macrófitas aquáticas no reservatório de Rosana, Sudeste do Brasil. Vinte espécies de peixes foram coletadas em quatro viagens, regularmente distribuídas em períodos de seca e chuva. Seis horas de observações subaquáticas pelo método animal focal foram realizadas. Nove espécies apresentaram abundâncias relativas maiores do que $1 \%$ e tiveram seus hábitos alimentares investigados. Hemigrammus marginatus, Roeboides paranensis, Hyphessobrycon eques, Astyanax altiparanae, Serrasalmus spilopleura e Bryconamericus stramineus foram predominantemente invertívoros, com predominância de insetos aquáticos (imaturos de Diptera, Ephemeroptera e Trichoptera). Os predominantemente algívoros foram Apareiodon affinis, Serrapinnus notomelas e Satanoperca pappaterra, com elevada ocorrência de algas cianofíceas filamentosas, diatomáceas, clorofíceas e periderme. A diferenciada exploração de microhabitats, em combinação com a dieta propriamente dita, sugere partilha dos recursos alimentares e ausência de competição por alimento entre as espécies 
mais representativas na comunidade de peixes estudada, ressaltando a importância de abordagens naturalísticas em estudos sobre ecologia de peixes.

Palavras-chave: macrófitas aquáticas, peixes, alimentação, reservatório de Rosana, rio Paranapanema.

\section{INTRODUCTION}

Aquatic macrophyte communities are often present along the littoral zone of water bodies harboring, among other organisms, a fish fauna characterized by small species or juveniles of species that grow to large sizes as adults, and offering them shelter and foraging places (Delariva et al., 1994). Furthermore, this microhabitat is also utilized as a spawning site by various fish species (Vazzoler \& Menezes, 1992). Fish communities associated with aquatic macrophytes take advantage of the food availability in this microhabitat (Rozas \& Odum, 1988), since macrophytes form a substratum where algae and bacteria may develop, and detritus may deposit, contributing to the abundance of invertebrates (Junk, 1973). This assumption may be indirectly investigated by stomach contents analysis of the fish community associated with these microhabitats.

Ecological interactions between fish communities and macrophytes in Brazil have been studied in the Amazon (Junk, 1973; Araújo-Lima et al., 1986; Soares et al., 1986) and Paraná basins (Delariva et al., 1994; Meschiatti et al., 2000). In the Upper Paraná River Basin, the damming of most rivers for hydroelectric power generation has increased the extent of the littoral zones and produced areas favorable for macrophtic development (Esteves, 1998). Specifically in the Paranapanema River, a large tributary of the Upper Paraná River, there are seven areas flooded for hydroelectric power generation. Despite the fact that damming is prevalent in the major rivers (Agostinho et al., 1992), the fish-macrophyte feeding interactions in the resultant reservoirs along the Paranapanema River have never been properly studied.

In the present investigation we studied the feeding habits of the fishes associated with aquatic macrophytes in order to evaluate the main food resources for the fish species within this microhabitat.

\section{MATERIAL AND METHODS}

\section{Study area}

Fieldwork was done along the right margin of an impounded portion of the Paranapanema River
(Fig. 1), in the Rosana Reservoir (22³6'45.7'S; $52^{\circ} 15^{\prime} 19.5$ ”'W), municipality of Teodoro Sampaio, State of São Paulo. The collection area was $65 \mathrm{~m}$ long and $10 \mathrm{~m}$ wide $\left(650 \mathrm{~m}^{2}\right)$ with a maximum depth of $1.10 \mathrm{~m}$. It has broad banks of aquatic macrophyte (Elodea sp., Sagittaria sp., Salvinia sp., and Eichhornia spp.). Chlorophyt mats are abundant mostly during the wet season. The climate is humid subtropical with two pronounced seasons, a dry one from April to September, and a wet one from October to March (Nimer, 1989).

\section{Sampling and analyses}

Physico-chemical data were recorded by digital equipment, horizontal water transparency was measured with a Secchi disk while skin diving; and rainfall and air temperature data were provided by the Weather Station in the Morro do Diabo State Park, Teodoro Sampaio.

The fishes were sampled at midday during both the dry (July and September of 2000) and wet (December of 2000 and March of 2001) seasons, using a hand seine $(20 \times 2 \mathrm{~m}, 5 \mathrm{~mm}$ mesh), and were preserved in $10 \%$ formalin. During each field trip, 10 seine hauls were made covering the entire sampled area, beginning at a maximum depth of 1.10 $\mathrm{m}$, following a perpendicular path towards the shore and dragging through the banks of macrophytes. In addition, during six daylight hours of focal animal snorkeling (sensu Lehner, 1996) observations were made during the daytime in order to observe the feeding behavior of the most abundant species. Gut contents were analyzed following the methods described by Bowen (1992).

Percent composition (Hynes, 1950) and frequency of occurrence (Bowen, 1992) were calculated for each item.

The similarity of the diets of the various fish species was calculated by Bray-Curtis Cluster Analysis using the BioDiversity-PRO software (version 2, McAlecee et al., 1997) and data on percent composition. Voucher specimens (LIRP 1813-63) are deposited in the Laboratório de Ictiologia de Ribeirão Preto (LIRP), Departamento de Biologia, Universidade de São Paulo, Brazil. 


\section{RESULTS}

\section{Physico-chemical characteristics of the study site}

The lowest air temperature recorded during the study period was in July $2000\left(-1.2^{\circ} \mathrm{C}\right)$ and the highest in October $2000\left(37.8^{\circ} \mathrm{C}\right)$. The lowest monthly rainfall was recorded in May 2000 (14.7 $\mathrm{mm})$ and the highest in December $2000(361 \mathrm{~mm})$. Water transparency ranged from 0.4 to $2.8 \mathrm{~m}$, conductivity from 50.0 to $56.9 \mu \mathrm{S} / \mathrm{cm}$, dissolved oxygen from 7.0 to $7.9 \mathrm{mg} / \mathrm{L}$, $\mathrm{pH}$ from 6.11 to 8.86 , and water temperature from 24.7 to $27.5^{\circ} \mathrm{C}$.

\section{Ichthyofauna}

Twenty fish species were collected, belonging to nine families, for a total of 2,244 specimens and a total biomass of $2,959 \mathrm{~g}$. Of these, 19 species were collected during the wet season and 14 during the dry season (Table 1). Abundance in terms of species was higher in the dry season whereas biomass was higher in the wet season (Table 1). Hemigrammus marginatus, Roeboides paranensis, and Serrapinnus notomelas were present in all collections. The most representative species (those with abundance higher than $1 \%$, Table 1) were the small-sized characiforms (H. marginatus, $R$. paranensis, Apareiodon affinis, $S$. notomelas, Hyphessobrycon eques, Astyanax altiparanae, and Bryconamericus stramineus) and juveniles of species that achieve large body sizes as adults (Serrasalmus spilopleura and Satanoperca pappaterra).

\section{Feeding habits}

The food items found in the gut contents of the nine most representative fish species were grouped according to their origin (Tables 2-3). A striking predominance of autochthonous items ( $78.4 \%$ of the total items) represented by diatoms, chlorophyts, and immature of Diptera, Ephemeroptera, and Trichoptera were found in the guts. The most utilized foraging sites are shown in Fig. 2. The similarity analysis of the percent composition for the fish diet showed two main trophic clusters (Fig. $3)$, depicted below.

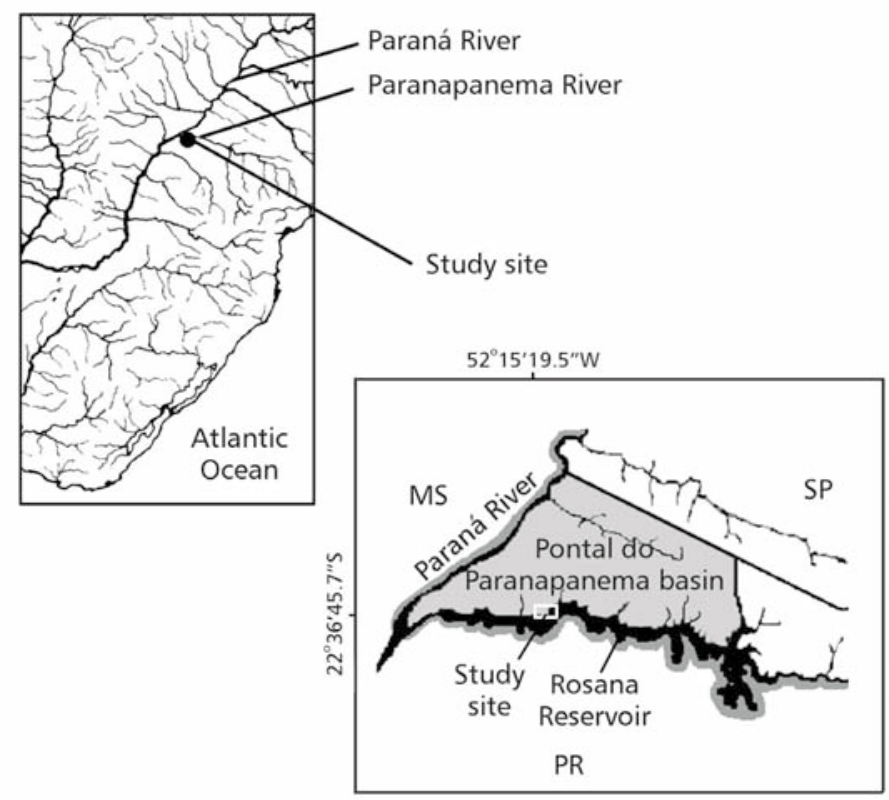

Fig. 1 - Location of the study site in the Rosana Reservoir, Paranapanema River, southeastern Brazil. 
TABLE 1

Fish species associated with macrophytes with their occurence (\% in parenthesis), number of collected specimens $(\mathrm{N})$, biomass (BM, g), range of standard length (SL, mm), relative total abundance $(\% \mathrm{~N})$ and relative total biomass (\% BM).

\begin{tabular}{|c|c|c|c|c|c|c|c|c|}
\hline \multirow[b]{2}{*}{ Taxa } & \multicolumn{3}{|c|}{ Dry season } & \multicolumn{3}{|c|}{ Wet season } & \multirow[b]{2}{*}{$\begin{array}{l}\% \\
\mathbf{N} \\
\end{array}$} & \multirow[b]{2}{*}{$\begin{array}{c}\% \\
\text { BM }\end{array}$} \\
\hline & $\mathbf{N}$ & $\mathbf{B M}$ & SL & $\mathbf{N}$ & $\mathbf{B M}$ & SL & & \\
\hline \multicolumn{9}{|l|}{ Characiformes } \\
\hline Hoplias malabaricus (50) & - & - & - & 8 & 740.0 & $19.8-287.0$ & 0.30 & 25.00 \\
\hline Astyanax altiparanae (75) & 35 & 133.0 & $38.4-73.7$ & 12 & 24.5 & $28.4-47.2$ & 2.10 & 5.30 \\
\hline Bryconamericus stramineus (75) & 17 & 6.0 & $23.9-33.4$ & 18 & 4.0 & $19.6-24.9$ & 1.70 & 0.20 \\
\hline Hemigrammus marginatus (100) & 1011 & 461.0 & $14.6-35.1$ & 218 & 117.5 & $14.4-33.8$ & 54.80 & 19.60 \\
\hline Hyphessobrycon eques (75) & 57 & 36.5 & $20.1-31.8$ & 70 & 58.5 & $24.5-31.2$ & 5.70 & 3.21 \\
\hline Oligosarcus pintoi (25) & - & - & - & 1 & 1.5 & 40.0 & 0.04 & 0.05 \\
\hline Aphyocharax anisitsi (75) & 3 & 1.5 & $31.1-36.0$ & 2 & 0.5 & $31.7-36.8$ & 0.20 & 0.06 \\
\hline Roeboides paranensis (100) & 316 & 272.0 & $26.9-52.2$ & 49 & 35.5 & $17.2-48.3$ & 16.30 & 10.30 \\
\hline Serrapinnus notomelas (100) & 103 & 62.5 & $19.0-31.5$ & 54 & 39.5 & $13.5-32.1$ & 7.00 & 3.50 \\
\hline Serrasalmus spilopleura (75) & 35 & 55.5 & $27.4-47.2$ & 12 & 11.0 & $15.3-49.6$ & 2.10 & 2.20 \\
\hline Acestrorhynchus lacustris (25) & - & - & - & 2 & 6.0 & $64.1-66.2$ & 0.08 & 0.20 \\
\hline Apareiodon affinis (50) & 41 & 18.0 & $19.2-39.4$ & 120 & 36.5 & $16.8-40.3$ & 7.20 & 1.90 \\
\hline Steindachnerina brevipinna (25) & 7 & 18.5 & $36.1-45.7$ & - & - & - & 0.30 & 0.60 \\
\hline \multicolumn{9}{|l|}{ Siluriformes } \\
\hline Loricariichthys labialis (25) & - & - & - & 1 & 2.0 & 67.6 & 0.04 & 0.06 \\
\hline Hypostomus ancistroides (50) & - & - & - & 2 & 8.5 & $26.3-65.7$ & 0.08 & 0.30 \\
\hline \multicolumn{9}{|l|}{ Gymnotiformes } \\
\hline Gymnotus carapo (50) & 1 & 2.0 & 87.1 & 2 & 4.0 & $79.7-91.0$ & 0.10 & 0.21 \\
\hline \multicolumn{9}{|l|}{ Synbranchiformes } \\
\hline Synbranchus marmoratus (50) & - & - & - & 1 & 42.5 & $25.5-213.8$ & 0.04 & 1.50 \\
\hline \multicolumn{9}{|l|}{ Perciformes } \\
\hline Cichlasoma paranaense (50) & 8 & 56.5 & $31.7-71.4$ & 1 & 70.0 & 105.6 & 0.40 & 4.30 \\
\hline Crenicichla britskii (75) & 2 & 1.0 & 20.4-34.7 & 3 & 63.5 & $48.3-132.2$ & 0.20 & 2.20 \\
\hline Satanoperca pappaterra (75) & 23 & 77.5 & $20.9-63.4$ & 9 & 495.0 & $10.3-159.9$ & 1.40 & 19.30 \\
\hline Total: 20 species & 1,659 & $1,198.5$ & - & 585 & $1,760.5$ & - & 100 & 100 \\
\hline
\end{tabular}

The invertivores were the most representative guild of the fish community, including six species. Microcrustaceans and immature aquatic Diptera, Ephemeroptera, and Trichoptera were the main feeding items exploited by the fish species included in this guild (Table 2).

For Astyanax altiparanae the allochthonous food items $(51.3 \%)$ were predominant, including Hymenoptera (Formicidae and Sphecidae), Diptera (mostly Drosophilidae found in the dry season), and seeds of Poaceae. Autochthonous items (41.6\%) were mostly represented by chironomid larvae (Tanytarsini and Orthocladiinae). Astyanax altiparanae was found alone or in groups of up to 20 individuals. The food items exploited by this species were mainly gathered from the water surface (surface picking, cf. Sazima, 1986), although individuals also collect items carried along by the water currents. 


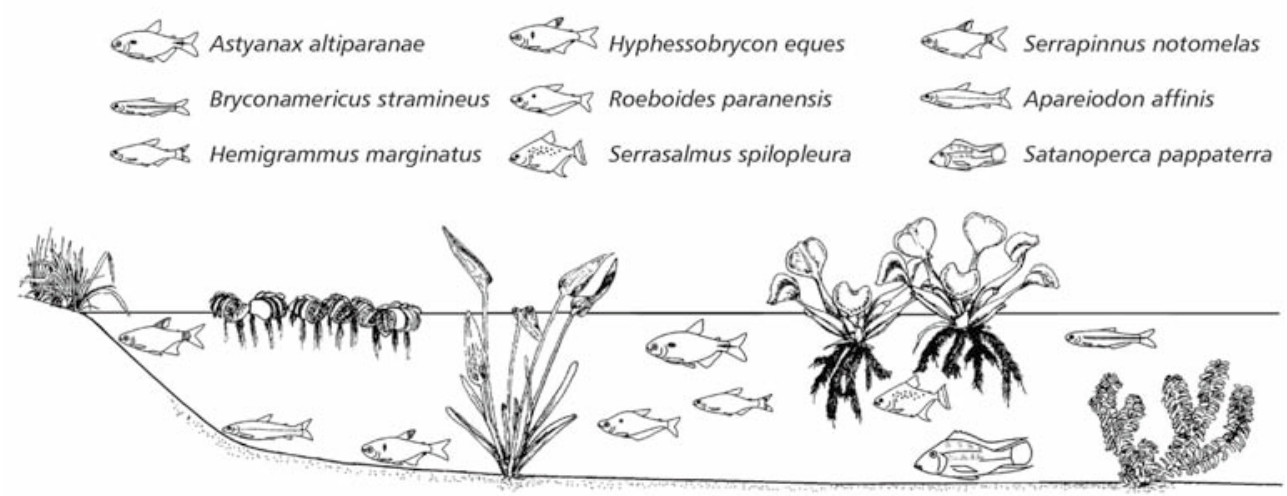

Fig. 2 - Spatial distribution during foraging activity of the fish community in the aquatic macrophyte banks.

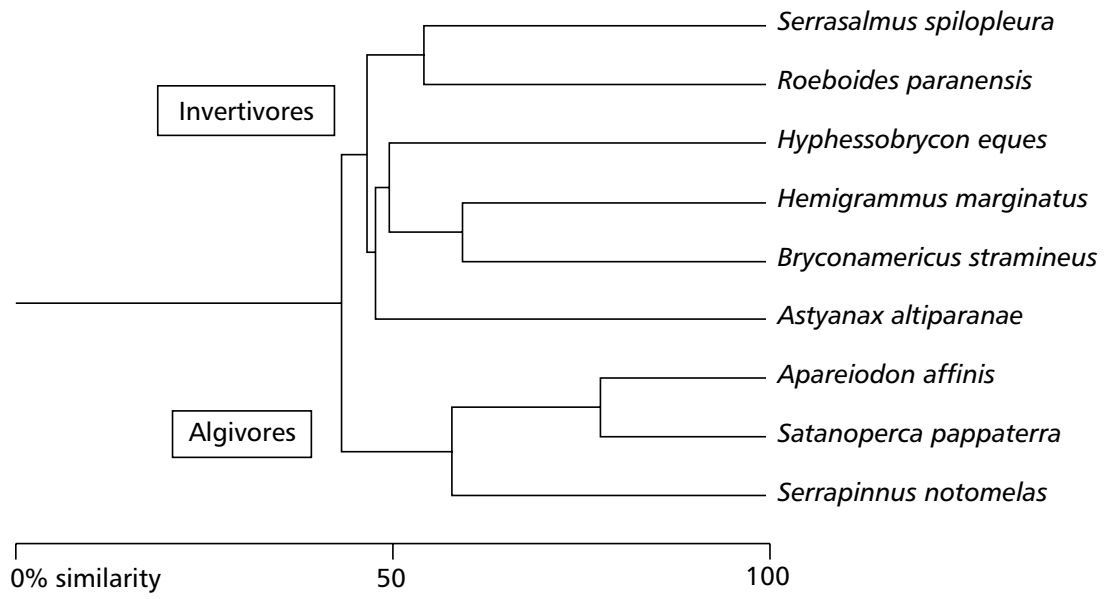

Fig. 3 - Dendrogram of similarity of the percent composition of the diet of the fish species in the aquatic macrophyte banks.

The individuals swim in the middle of the water column, but always pay attention to the water surface. Whenever a particle is detected falling into the water, they rapidly move towards and bite it. If the prey item is unpalatable it is rapidly rejected. Comparisons between the two seasons was hampered by the fact that of 26 specimens examined, only 5 were collected during the wet season. Bryconamericus stramineus had a predominance of animal items of autochthonous origin $(54.2 \%)$ in its diet, represented mainly by dipteran larvae (mostly pupae and larvae of Chironomidae, mostly Tanytarsini and Chironomini) that were present during both seasons. Among allochthonous items (43.2\%), the most frequent were adult Diptera (mostly Drosophilidae, present in the dry season). Only a few individuals were observed in groups of up to four specimens swimming from midwater to the surface.

For Hemigrammus marginatus autochthonous items were predominant (77.2\%) in both seasons. In the dry season dipteran larvae and pupae (Chironomidae) and algae were the main items while during the wet season dipteran pupae and larvae (Chironomidae), Cladocera (Daphniidae), and Copepoda (Cyclopoida) were dominant. In both seasons chironomid pupae were numerically dominant in the gut contents. Schools of 30 to 50 specimens including juveniles and adults were observed swimming in the middle of the water column. 
TABLE 2

Number of examined specimens (N), standard length (SL), number of empty stomachs (N Empty), number of stomachs with Nematoda parasites ( $N$ Nematoda), number of stomachs with sediment ( $N$ Sediment), frequency of occurrence (fo) and percent composition (pc) of the allochthonous and autochthonous items found in the diet of the predominantly invertivorous fish species associated with aquatic macrophytes.

\begin{tabular}{|c|c|c|c|c|c|c|}
\hline Items & $\begin{array}{c}\text { A. } \\
\text { altiparanae }\end{array}$ & $\begin{array}{c}\text { B. } \\
\text { stramineus }\end{array}$ & $\underset{\text { marginatus }}{\mathrm{H} .}$ & $\begin{array}{c}H . \\
\text { eques }\end{array}$ & $\begin{array}{c}R . \\
\text { paranensis }\end{array}$ & $\begin{array}{c}S . \\
\text { spilopleura }\end{array}$ \\
\hline $\mathrm{N}$ & 24 & 20 & 40 & 30 & 30 & 22 \\
\hline SL (mm) & $28.1-48.3$ & $22.2-32.6$ & $17.7-32.2$ & $24.4-31.6$ & $22.7-46.9$ & $18.1-49.3$ \\
\hline N Empty & - & 1 & 1 & - & - & - \\
\hline N Nematoda & - & - & 27 & 6 & - & - \\
\hline \multirow[t]{2}{*}{ N Sediment } & - & 2 & - & 14 & - & 15 \\
\hline & fo/pc & fo/pc & fo/pc & fo/pc & fo/pc & fo/pc \\
\hline \multicolumn{7}{|l|}{ Allochthonous items } \\
\hline Seeds & $33.0 / 11.4$ & - & - & $3.3 / 1.6$ & $6.7 / 3.2$ & - \\
\hline Araneae & - & $5.0 / 2.2$ & - & - & - & - \\
\hline Acarina & - & $15.0 / 6.5$ & - & $3.3 / 1.6$ & - & - \\
\hline Thysanoptera & - & $10.0 / 4.4$ & - & - & - & - \\
\hline Hemiptera & - & - & $2.5 / 0.9$ & - & - & - \\
\hline Hymenoptera & $66.7 / 22.8$ & $25.0 / 10.9$ & $12.5 / 3.8$ & - & - & - \\
\hline Coleoptera & - & - & $2.5 / 0.9$ & - & $3.3 / 1.6$ & - \\
\hline Diptera & $50.0 / 17.1$ & $40.0 / 17.4$ & $27.5 / 10.6$ & - & - & $13.6 / 6.1$ \\
\hline Adult insect fragments & - & $5.0 / 2.2$ & $2.5 / 0.9$ & - & $10.0 / 4.8$ & - \\
\hline \multicolumn{7}{|l|}{ Autochthonous items } \\
\hline Algae & $8.3 / 2.9$ & $25.0 / 10.7$ & $37.5 / 14.4$ & - & $13.3 / 6.4$ & $36.4 / 16.4$ \\
\hline Nematoda & - & $10.0 / 4.4$ & - & - & - & - \\
\hline Bivalvia & $8.3 / 2.9$ & - & - & - & - & - \\
\hline Gastropoda & $29.1 / 10.0$ & - & - & - & $6.7 / 3.2$ & - \\
\hline Hirudinae & - & - & $2.5 / 0.9$ & - & - & - \\
\hline Oligochaeta & - & - & $2.5 / 0.9$ & - & - & - \\
\hline Copepoda & $4.1 / 1.4$ & $5.0 / 2.2$ & $27.5 / 10.5$ & $46.7 / 22.2$ & $20.0 / 9.6$ & $4.5 / 2.0$ \\
\hline Cladocera & - & $5.0 / 2.2$ & $42.5 / 16.2$ & $46.7 / 22.2$ & $13.3 / 6.4$ & $13.6 / 6.1$ \\
\hline Ostracoda & $4.1 / 1.4$ & - & $12.5 / 3.8$ & $26.7 / 12.7$ & - & $4.5 / 2.0$ \\
\hline Hydracarina & - & - & - & $23.3 / 11.1$ & - & - \\
\hline Odonata & $8.3 / 2.9$ & - & - & - & $10.0 / 4.8$ & - \\
\hline Hemiptera & $4.1 / 1.4$ & - & - & - & - & - \\
\hline Hymenoptera & $4.1 / 4.2$ & - & $2.5 / 0.9$ & - & - & - \\
\hline Diptera & $41.6 / 14.3$ & $75.0 / 32.5$ & $67.5 / 25.7$ & $33.3 / 15.9$ & $40.0 / 19.3$ & $22.7 / 10.2$ \\
\hline Ephemeroptera & $4.1 / 1.4$ & $5.0 / 2.2$ & $5.0 / 1.9$ & $6.7 / 3.2$ & $43.3 / 20.9$ & $36.4 / 16.5$ \\
\hline Trichoptera & $8.3 / 2.9$ & - & - & $6.7 / 3.2$ & $36.7 / 17.7$ & $27.3 / 12.2$ \\
\hline Scales & - & - & $5.0 / 1.9$ & - & $3.3 / 1.6$ & $27.3 / 12.2$ \\
\hline Fish & - & - & - & - & - & $13.6 / 6.1$ \\
\hline \multicolumn{7}{|l|}{ Unknown origin } \\
\hline Fungi & - & $5.0 / 2.2$ & - & - & - & - \\
\hline Vegetable matter & - & - & $5.0 / 1.9$ & - & - & $22.7 / 10.2$ \\
\hline Animal matter & $16.7 / 5.7$ & - & $5.0 / 1.9$ & $13.3 / 6.3$ & - & - \\
\hline Microhymenoptera & $4.1 / 1.4$ & - & $5.0 / 1.9$ & - & - & - \\
\hline
\end{tabular}


The feeding tactics and diet of B. stramineus and $H$. marginatus are similar. Both species collected food items carried by the current (drift-feeding, cf. Grant \& Noakes, 1987), mostly tube-building dipterans associated with macrophyte stems (Tanytarsini and Chironomini), and sometimes terrestrial insects taken from the surface (surface picking, cf. Sazima, 1986).

For Hyphessobrycon eques animal items of autochthonous origin $(90.5 \%)$ were predominant, among them dipteran larvae (Tipulidae and Chironomidae), Copepoda, and Cladocera (Chydoridae and Daphniidae) in the dry season, and Copepoda, Cladocera, and Ostracoda in the wet season, in that order. Hyphessobrycon eques was observed in groups of 20 to 30 specimens in the water column close to the substrate. They permanently patrol the substrate with an inclined posture, heads directed to the substrate. Often they thrust against roots of macrophytes or the substrate and collect small prey items (picking at small prey, cf. Keenleyside, 1979).

Roeboides paranensis had a predominance of animal items of autochthonous origin (90.9\%) in its diet. In both seasons the main food items were Trichoptera larvae (mainly Hydroptilidae), Diptera larvae (mainly Chironomidae), and Ephemeroptera nymphs (Baetidae). In the wet season Copepoda and blue-green algae were also frequently utilized. Roeboides paranensis were observed in groups of about 20 specimens, generally close to shoals of H. marginatus.

Serrasalmus spilopleura had a predominance of animal items of autochthonous origin in its diet $(83.7 \%)$. The most representative items were Ephemeroptera nymphs (Caenidae) in the dry season and Trichoptera larvae (Hydroptilidae) in the wet season. Scales and fish remains were found in specimens larger than $30 \mathrm{~mm}$ SL. No individual was observed during snorkeling. The predominantly algivore species are Serrapinnus notomelas, Apareiodon affinis, and Satanoperca papaterra (Table 3), with a high percentage of autochthonous items in the diet (more than $90 \%$ ). For $S$. notomelas the main item during both seasons was filamentous blue-green algae (58.7\%), followed by dipteran larvae (Chironomidae, Tipulidae, and Ceratopogonidae, 17\%). Sediment and parasite nematodes were found in $43 \%$ and $29 \%$ of the analyzed stomachs, respectively. The juveniles of $S$. notomelas were often observed among shoals of $H$. marginatus, in groups of up to 25 specimens, whereas the adults were observed in smaller groups. Juveniles and adults swim from midwater to the bottom and bite patches of algae close to the roots of macrophyte in shallower areas (nibblers, cf. Sazima, 1986).

In both seasons $A$. affinis ingested diatoms (mainly Tabellaria, Gomphoneis, Bacillaria, Amphora, Fragillaria, Navicula, and Gomphonema), clorophytes (mostly Spirogyra, Oedogonium, Mesotaenium, and Cosmarium), and macrophyte periderm. Sediment was found in $40 \%$ of the individuals analyzed. No individual was observed during snorkeling.

Satanoperca pappaterra ingested mostly diatoms, periderm, clorophyts, and microcrustaceans. Pairs of individuals were found foraging over the bottom. The individuals are supported by the caudal peduncle while motionless. While foraging they plunge their mouths into the substrate, fill it with sediment, and expel unpalatable items through the mouth or opercular openings (diggers of localized excavations, cf. Sazima, 1986).

\section{DISCUSSION}

\section{Ichthyofauna}

The predominance of small characids among macrophytes has also been found by other authors in the Amazon (Junk, 1973; Araújo-Lima et al., 1986) and Paraná basins (Delariva et al., 1994; Meschiatti et al., 2000), being associated with favorable environmental conditions in terms of shelter, dissolved oxygen, and food (Delariva et al., 1994). In general the macrophyte habitat not only provides protection from predators, but also rich foraging microhabitats for fishes (Castro \& Arcifa, 1987), allowing higher growth rates and fecundity, and lower mortality (Rozas \& Odum, 1988).

The higher abundance of species found during the dry season, which were mostly represented by small-sized characids, reflects a higher density of specimens seeking protection and food as water level decreases (Delariva et al., 1994).

Alternatively, the presence of the large piscivore Hoplias malabaricus during the wet season is probably due to the rise in water level, which increases the availability of potential prey (LoweMcConnell, 1987).

\section{Feeding habits}

Despite high dietary similarity (more than 50\%) demonstrated by the predominantly invertivorous fish species, either a hypothesized abundance of resources and/or its differential exploitation (see Fig. 2) may be factors that minimize possible competitive interactions among these species (cf. Ross, 1986). 
TABLE 3

Number of examined specimens (N), standard length (SL), number of empty stomachs (N Empty), number of stomachs with Nematoda parasites ( $N$ Nematoda), number of stomachs with sediment ( $N$ Sediment), frequency of occurrence (fo) and percent composition (pc) of the allochthonous and autochthonous items found in the diet of the predominantly algivorous fish species associated with aquatic macrophytes.

\begin{tabular}{|c|c|c|c|}
\hline Items & S. notomelas & A. affinis & S. pappaterra \\
\hline $\mathrm{N}$ & 28 & 30 & 15 \\
\hline $\mathrm{SL}(\mathrm{mm})$ & $16.7-31.5$ & $22.9-40.0$ & $20.8-57.0$ \\
\hline N Empty & - & - & - \\
\hline N Nematoda & 8 & - & - \\
\hline \multirow[t]{2}{*}{ N Sediment } & 12 & 12 & 11 \\
\hline & fo/pc & fo/pc & fo/pc \\
\hline \multicolumn{4}{|l|}{ Allochthonous } \\
\hline Oligochaeta & $3.5 / 2.4$ & - & - \\
\hline Adult insect fragments & $3.5 / 2.4$ & - & - \\
\hline \multicolumn{4}{|l|}{ Autochthonous } \\
\hline Cyanophyceae (filamentous) & $85.7 / 58.7$ & $6.6 / 2.2$ & $13.3 / 3.1$ \\
\hline Bacillariophyceae & - & $90.0 / 32.0$ & $93.3 / 21.9$ \\
\hline Chlorophyta & - & $56.7 / 20.0$ & $80.0 / 18.7$ \\
\hline Charophyta & - & $6.6 / 2.2$ & - \\
\hline Periderm & - & $93.3 / 32.8$ & $100.0 / 23.4$ \\
\hline Copepoda & $3.5 / 2.4$ & - & - \\
\hline Cladocera & $3.5 / 2.4$ & - & - \\
\hline Ostracoda & $10.7 / 7.5$ & - & - \\
\hline Amphipoda & - & - & $53.3 / 12.5$ \\
\hline Malacostraca & - & - & $6.6 / 1.6$ \\
\hline Díptera & $25.0 / 17.0$ & - & $6.6 / 1.6$ \\
\hline Ephemeroptera & $3.5 / 2.4$ & - & - \\
\hline Juvenile insect fragments & $3.5 / 2.4$ & - & - \\
\hline Scales & $3.5 / 2.4$ & - & - \\
\hline \multicolumn{4}{|l|}{ Unknown origin } \\
\hline Organic matter & - & $30.0 / 10.8$ & $73.3 / 17.2$ \\
\hline
\end{tabular}

The diet of A. altiparanae (= A. bimaculatus in the upper Paraná River basin) has been relatively well studied in streams (Castro \& Casatti, 1997) and in reservoirs (Arcifa et al., 1991; Arcifa \& Meschiatti, 1993; Esteves \& Galetti, 1995; Esteves, 1996). This species demonstrates opportunistic-omnivorous habits, feeding on zooplankton, algae, and macrophytes when insects are scarce (Arcifa et al., 1991) and preying both in the water column and on the sediment. Although individuals were observed feeding only on items on the water surface in the present study, the gut contents analysis corroborated their feeding flexibility since both allochthonous animal and vegetal items (Formicidae, Sphecidae, Drosophilidae, and Poaceae seeds) and benthic autochthonous items (Tanytarsini, Orthocladiinae, Ceratopogonidae, and Ephemeroptera) were ingested.

Although the diet of B. stramineus and $H$. marginatus are similar, $B$. stramineus collected items from the surface more frequently. This differential exploitation of the resources was also indicated by the higher occurrence of allochthonous items in its 
stomach relative to $H$. marginatus and probably minimizes the degree of feeding overlap between the two species.

The scarce occurrence of scales (3.3\%) in the stomachs of $R$. paranensis disagrees with the lepidophagous behavior previously described for this species (Sazima \& Machado, 1982; Sazima, 1983). According to Sazima \& Machado (1982), R paranensis is a diurnal stalk predator, apparently preferring midwater prey items. These authors also found aquatic insects occurring in $50 \%$ of the specimens analyzed and scales in $93 \%$. In the present study, the main feeding items (Baetidae, Hydroptilidae, and Chironomidae) indicate that this species at this specific site feeds among macrophytes stems, and the low proportion of scales suggests a possible facultative lepidophagous behavior, especially when other food items are scarce.

Serrasalmus spilopleura was represented by young specimens (up to $49.3 \mathrm{~mm} \mathrm{SL}$ ) and the diet of the specimens of up to $30 \mathrm{~mm}$ SL was mainly insectivorous, with no fish fragments recorded. Nevertheless, several authors have found fin fragments in the stomachs of individuals larger than 24 mm SL (Sazima \& Zamprogno, 1985) and in postlarvae of $18.5 \mathrm{~mm}$ SL (Northcote et al., 1987). According to Sazima \& Zamprogno (1985), not only does the diet change ontogenetically, but also the hunting tactic, with the adults becoming adapted to patrolling in open water. Although algae are present in $36.4 \%$ of the analyzed stomachs and vegetable matter in $22.7 \%$, the ingestion of vegetable items has been considered accidental (Sazima \& Machado, 1990), as was the ingestion of sediment observed in the present study.

In the present study $S$. pappaterra has been included among the predominantly algivorous species, a finding different from that showing the predominance of insect larvae, crustaceans, plant debris, and loose scales in the diet reported by Sazima (1986). In contrast, the foraging tactic observed in this study seems to be the same described by Sazima (1986) suggesting higher fidelity to the mode of obtaining food than to the type of food and revealing dietary flexibility in this species. Other algivorous species foraged at different sites as discussed below.

The presence of sand grains in about one-half of the stomachs of $S$. notomelas, together with benthic larvae (Chironomidae, Tipulidae, and Ceratopogonidae), indicates that the food is being taken from the bottom, a finding in agreement with that of Luiz et al. (1998) and our underwater observations. The classification of $S$. notomelas in this guild is due to the higher occurrence of bluegreen algae in its stomach, relative to the presence of insect larvae. However, at this point it is impossible to conclude whether insects are accidentally captured during the ingestion of algae or vice versa.

Sazima (1980) found algae, insect larvae, pieces of vascular plants, and organic and inorganic particles in the stomachs of subadults ( 17 to $22 \mathrm{~mm} \mathrm{SL}$ ) of A. piracicabae in the Atibaia River, Southeastern Brazil. Although we did not observe A. affinis during underwater observations, parodontids are diurnal and are often found grazing on algae on the substrate (Sazima, 1980; Casatti \& Castro, 1998). It is possible that in the present study the foraging sites included, in addition to the substrate, the stems and roots of macrophytes, because more than $90 \%$ of the stomachs included pieces of periderm probably removed from submerged plants while the fish grazes on the periphyton.

In conclusion, the small-sized fish species (mostly small characiforms) that inhabit banks of aquatic macrophytes feed mainly on autochthonous items, represented by diatoms, chlorophyts, microcrustaceans, and immatures of Diptera, Ephemeroptera, and Trichoptera. Directly or indirectly, these prey items depend on detritus and periphyton supported by the aquatic macrophytes (Junk, 1973) which thus serve as an important foraging micro-habitat for small-sized fish species in rivers and reservoirs.

Diet composition and the differential microhabitat exploitation observed suggest partitioning of the food resources among the fish species and absence of food competition. Such a conclusion could only be reached through data obtained from underwater observations, which once again emphasizes the importance of this approach to the study of fish ecology (cf. Sazima, 1986).

Acknowledgments - We thank H. F. Santos, L. S. F. Martins, R. Stopiglia, and F. Langeani for help with the field work; A. L. A. Melo for assistance with macrophyte identification; Instituto Florestal-SP, Morro do Diabo State Park, IBAMA for collecting permits, and Departamento de Biologia FFCLRP-USP for facilities during this work; C. A. Lucena and F. Langeani for help with fish identification; and R. M. C. Castro, C. G. Froehlich, M. S. Arcifa, and R. P. Vari for suggestions on improving the manuscript. This work was partially supported by the State of São Paulo Research Foundation (FAPESP) within the BIOTA/FAPESP Program - The 
Biodiversity Virtual Institute Program (www.biota.org.br) through the Thematic Project "Fish diversity of the headwaters and streams of the upper Paraná River system in the State of São Paulo, Brazil" (FAPESP n. 98/05072-8) and by PRONEX Project "Conhecimento, Conservação e Utilização Racional da Diversidade da Fauna de Peixes do Brasil" (FINEP/CNPq n. 661058/1997-2). The authors receive grants from FAPESP (n. 00/01919-8, 00/05903-9 and 00/ 01918-1).

\section{REFERENCES}

AGOSTINHO, A. A., JÚLIO-JR., H. F. \& BORGHETTI, J. R., 1992, Considerações sobre os impactos dos represamentos na ictiofauna e medidas para sua atenuação. Um estudo de caso: reservatório de Itaipu. Rev. Unimar, 14: 89-107.

ARAÚJO-LIMA, C. A. M. R., PORTUGAL, L. P. S. \& FERREIRA, E. G., 1986, Fish-macrophyte relationship in the Anavilhanas Archipelago, a black water system in the Central Amazon. J. Fish. Biol., 29: 1-11.

ARCIFA, M. S. \& MESCHIATTI, A. J., 1993, Distribution and feeding ecology of fishes in a Brazilian Reservoir: Lake Monte Alegre. Interciencia, 18: 302-313.

ARCIFA, M. S., NORTHCOTE, T. G. \& FROEHLICH, O., 1991, Interactive ecology of two cohabiting characin fishes (Astyanax fasciatus and Astyanax bimaculatus) in an eutrophic Brazilian reservoir. J. Trop. Ecol., 7: 257-268.

BOWEN, S. H., 1992, Quantitative description of the diet, pp. 325-336. In: L. A. Nielsen \& D. L. Johnson (eds.), Fisheries techniques. American Fisheries Society, Bethesda, 468p.

CASATTI, L. \& CASTRO, R. M. C., 1998, A fish community of the São Francisco River headwaters riffles, Southeastern Brazil. Ichthyol. Explor. Freshwaters, 9: 229-242.

CASTRO, R. M. C. \& ARCIFA, M. S., 1987, Comunidades de peixes de reservatórios no Sul do Brasil. Rev. Bras. Biol., 47: 493-500

CASTRO, R. M. C. \& CASATTI, L., 1997, The fish fauna from a small forest stream of the upper Paraná River basin, Southeastern Brazil. Ichthyol. Explor. Freshwaters, 7: 337-352.

DELARIVA, R. L., AGOSTINHO, A. A., NAKATANI, K. \& BAUMGARTNER, G., 1994, Ichthyofauna associated to aquatic macrophytes in the Upper Paraná River floodplain. Rev. Unimar, 16: 41-60.

ESTEVES, F. A., 1998, Fundamentos de limnologia. Interciência, Rio de Janeiro, 602p.

ESTEVES, K. E., 1996, Feeding ecology of three Astyanax species (Characidae, Tetragonopterinae) from a floodplain lake of Mogi-Guaçu River, Paraná River Basin, Brazil. Environm. Biol. Fishes, 46: 83-101.

ESTEVES, K. E. \& GALETTI Jr., P. M., 1995, Food partitioning among some characids of a small Brazilian floodplain lake from the Paraná River basin. Environm. Biol. Fishes, 42: 375-389.

GRANT, J. W. A. \& NOAKES, D. L. G., 1987, A simple model of optimal territory size for drift-feeding fishes. Can. J. Zool., 65: 270-276.

JUNK, W. J., 1973, Investigations on the ecology and productionbiology of the "floating meadows" (Paspalo-Echinochloetum) on the middle Amazon. II. The aquatic fauna in the root-zone of floating vegetation. Amazoniana, 4: 9 102.

Braz. J. Biol., 63(2): 213-222, 2003
KEENLEYSIDE, M. H. A., 1979, Diversity and adaptation in fish behaviour. Springer, Berlin, 208p.

HYNES, H. B. N., 1950, The food of fresh-water sticklebacks (Gasterosteus aculeatus and Pygosteus pungitius), with a review of methods used in studies of the food of fishes. $J$. Anim. Ecol., 19: 36-57.

LEHNER, P. N., 1996, Handbook of ethological methods. Cambridge University Press, Cambridge, 672p.

LOWE-McCONNELL, R. H., 1987, Ecological studies in tropical fish communities. Cambridge Univ. Press, Cambridge, 382p.

LUIZ, E. A., AGOSTINHO, A. A., GOMES, L. C. \& HAHN, N. S., 1998, Ecologia trófica de peixes em dois riachos da bacia do Rio Paraná. Rev. Brasil. Biol., 58: 272-285.

McAlECEE, N., LAMBSHEAD, P. J. D., PATERSON, G. L. J. \& GAGE, J. D., 1997, BioDiversity Professional (software). Beta-Version. The Natural History Museum and The Scottish Association for Marine Sciences.

MESCHIATTI, A. J., ARCIFA, M. S. \& FENERICH-VERANI, N., 2000, Fish communities associated with macrophytes in Brazilian floodplain lakes. Environ. Biol. Fishes, 58: 133-143.

NIMER, E., 1989, Climatologia do Brasil. Secretaria de Planejamento e Coordenação da Presidência da República e IBGE, Rio de Janeiro, 421p.

NORTHCOTE, T. G., ARCIFA, M. S. \& FROEHLICH, O., 1987, Fin-feeding by the piranha (Serrasalmus spilopleura Kner): the cropping of a novel renewable resource. Proc. $5^{\text {th }}$ Congr. Europ. Ichthyol., Stockholm, 1985, pp. 133-143.

ROSS, S. T., 1986, Resource partitioning in ecological communities. Science, 185: 27-39.

ROZAS, L. P. \& ODUM, W. E., 1988, Occupation of submerged aquatic vegetation by fishes: testing the roles of food and refuge. Oecologia, 77: 101-106.

SAZIMA, I., 1980, Behavior of two Brazilian species of parodontid fishes, Apareiodon piracicabae and A. ibitiensis. Copeia, pp. 166-169.

SAZIMA, I., 1983, Scale-eating in characoids and other fishes. Environm. Biol. Fishes, 9: 87-101.

SAZIMA, I., 1986, Similarities in feeding behaviour between some marine and freshwater fishes in two tropical communities. J. Fish. Biol., 29: 53-65.

SAZIMA, I. \& MACHADO, F. A., 1982, Hábitos e comportamentos de Roeboides prognathus, um peixes lepidófago (Osteichthyes, Characoidei). Bolm. Zool., Univ. S. Paulo, 7: 37-56.

SAZIMA, I. \& ZAMPROGNO, C., 1985, Use of water hyacinths as shelter, foraging place, and transport by young piranhas, Serrasalmus spilopleura. Environm. Biol. Fishes, 12: 237240.

SAZIMA, I. \& MACHADO, F. A., 1990, Underwater observations of piranhas in western Brazil. Environm. Biol. Fishes, 28: 17-31.

SOARES, M. G. M., ALMEIDA, R. G. \& JUNK, W. J., 1986, The trophic structure of the fish fauna in Camaleão, a macrophyte dominated floodplain lake in the middle Amazon. Amazoniana, 9: 511-526.

VAZZOLER, A. E. A. M. \& MENEZES, N. A., 1992, Síntese de conhecimentos sobre o comportamento reprodutivo dos Characiformes da América do Sul (Teleostei, Ostariophysi). Rev. Brasil. Biol., 52: 627-640. 